\title{
Synthesis of Fly Ash Magnetic Glass Microsphere@BiVO and Its Hybrid Action of Visible-Light Photocatalysis and Adsorption Process
}

\author{
Ting Cheng ${ }^{1,2}$, Chen Chen ${ }^{3 *}$, Lei Wang ${ }^{3}$, Xiao Zhang ${ }^{1,2}$, Chenhao Ye ${ }^{3}$, \\ Qin Deng ${ }^{3}$, Gang Chen ${ }^{3}$
}

${ }^{1}$ School of Environmental Ecology, Jiangsu City Vocational College,Nanjing, China

${ }^{2}$ Nanjing University and Yancheng Academy of Environmental Technology and Engineering, Yancheng, China ${ }^{3}$ School of Environmental and Chemical Engineering, Jiangsu University of Science and Technology, Zhenjiang, China

Received: 24 June 2020

Accepted: 27 September 2020

\begin{abstract}
A novel composite photocatalyst (fly ash magnetic glass microsphere $@ \mathrm{BiVO}_{4}$, called $\mathrm{FaBi}$ ), where the magnetic glass microsphere (from fly ash) was used as magnetic carriers for $\mathrm{BiVO}_{4}$, was synthesized. The properties of composite photocatalyst were characterized by XRD, FT-IR, SEM, XPS, UV-vis, magnetic hysteresis loop and DFT caculation. After the synthesis reaction, the smaller spherical $\mathrm{BiVO}_{4}(2-4 \mu \mathrm{m})$ was successfully loaded on the surface of magnetic glass microspheres. The composite catalyst of $\mathrm{FaBi}$ had obvious ferromagnetism, and the saturation magnetization was $27.52 \mathrm{emu} / \mathrm{g}$. The photocatalytic experiments results showed that the composite catalyst could effectively degrade MB (Methylene blue) in the solution under visible light excitation. The apparent degradation process of MB was satisfactorily fitted by the first-order reaction kinetics. After several times of recycling, the photocatalysis of the material remained basically stable. The photocatalytic degradation of MB in solution was mainly due to the direct oxidation of free holes and related free radical reaction. The efficient adsorption of MB from solution was ascribed to large specific surface area of composite catalyst. The adsorption process was well modeled by the pseudo-first-order kinetic equation and Langmuir adsorption isotherm. The adsorption function enhanced the degradation effect of photocatalysis for target pollutant in solution. DFT calculation verified the photocatalytic properties of $\mathrm{BiVO}_{4}$ (calculated energy band is $2.213 \mathrm{eV}$ ) under visible light. The fly ash magnetic glass microsphere could be used as an excellent magnetic carrier for photocatalyst materials.
\end{abstract}

Keywords: $\mathrm{BiVO}_{4}$, magnetic glass microsphere, photocatalysis, adsorption

*e-mail: chenc@just.edu.cn 


\section{Introduction}

With continuous development of chemical companies and discharge of pollutants, people pay more attention to the problem of water pollution. Among them, organic pollution is a prominent problem of water pollution in our country. At present, the main organic pollutants are pesticides, phenols, cyanide, oil and so on. However, organic pollutants are not easy to degrade in water. These substances have a certain degree of bioaccumulation in the environment, most of them are toxic, and some of them even have the effect of "three causes" [1]. If treated improperly, organic pollutants would lead to the death of animals and plants, damage of soil structure, and even a threat to human health. Therefore, we must take appropriate methods to remove organic pollutants in water.

At present, there are many methods for treatment of organic pollutants in wastewater. The commonly used ways are biological method [2, 3], adsorption method $[4,5]$, oxidation method $[6,7]$, Fenton method [8], and so on. The biological method has advantages of low consumption, high efficiency, convenient and reliable process operation and management, and no secondary pollution, while the cost is higher and the microorganism is difficult to domesticate; The operation of adsorption method is relatively simple, but the regeneration of adsorbents is difficult, and the cost is very expensive; The reaction of oxidation method is mild and easy to control, whereas the efficiency is relatively low, and the strong oxidant costs a lot; Fenton method has advantages of simple operation, rapid reaction and flocculation, nevertheless, $\mathrm{H}_{2} \mathrm{O}_{2}$ is highly expensive. The photocatalysis technology, a technology that uses a new type of composite environmental functional materials, is widely used in air purification, water purification, self-purification, sterilization and deodorization, antifouling and antifogging, and other fields. The technology has superiorities of strong oxidation, mild reaction conditions, thorough purification, low price, and environment-friendly.

According to related literatures [9-15], there are a variety of catalysts in photocatalysis, such as $\mathrm{TiO}_{2}, \mathrm{ZnO}$, $\mathrm{BiVO}_{4}, \mathrm{ZrO}_{2}, \mathrm{CdS}, \mathrm{C}_{3} \mathrm{~N}_{4}$, and so forth. Among them, $\mathrm{BiVO}_{4}$ is a widely used photocatalytic material due to its better absorption property for visible light. Moreover, synthetic materials have a wide range of sources, low price and excellent chemical stability. Thus, $\mathrm{BiVO}_{4}$ is a good photocatalytic material with strong potential for development. Zhu prepared $\mathrm{BiVO}_{4}$ photocatalytic materials by hydrothermal synthesis to degrade RhB, and obtained a good degradation effect [16]; Wang synthesized $\mathrm{BiVO}_{4}$ with surface heterojunction by low temperature water without additives, and proved that co-exposed (010) and (110) faces had the highest photocatalytic activity [17]. Using monoclinic $\mathrm{BiVO}_{4}$ as catalyst, Ullah studied p-type $\mathrm{BiVO}_{4}(001)$ after oxygen defects and selenium doping, and confirmed that the photocatalytic material could effectively absorb the visible part of sunlight and decompose water into $\mathrm{O}_{2}$ and $\mathrm{H}_{2}$ [18].

Although photocatalytic materials have good photocatalytic performances, it is troublesome for them to separate. In order to solve this problem, the existing idea is to composite them with magnetic materials. Wang loaded $\mathrm{BiVO}_{4}$ on magnetite particles to prepare a magnetically separable visible light photocatalyst of $\mathrm{BiVO}_{4} / \mathrm{Fe}_{3} \mathrm{O}_{4}$, which could be recovered after photocatalytic degradation [19]; Ke synthesized $\mathrm{BiVO}_{4}-\mathrm{Fe}_{3} \mathrm{O}_{4}$ by solvo-thermal method and used it as photo-reduction catalyst to remove $\mathrm{Cr}$ (VI) from water under visible light irradiation [20]; Yan prepared magnetically separable visible light photocatalyst $\mathrm{BiVO}_{4} / \mathrm{Fe}_{3} \mathrm{O}_{4}$, by the degradation of methylene blue (MB) under visible light [21]. In the above sources, the magnetic base used is $\mathrm{Fe}_{3} \mathrm{O}_{4}$, which is a high cost material, so we are committed to looking for a low-cost magnetic base.

Fly ash is a by-product of coal combustion. According to the situation of coal used in our country, burning 1ton of coal produces $250 \sim 300 \mathrm{~kg}$ fly ash. If a large amount of fly ash is not controlled or treated, it will enter the water body and silt the river, cause air pollution, and bring harm to biology and human body. The main chemical composition of magnetic part of fly ash is $\mathrm{Fe}_{2} \mathrm{O}_{3}$ and $\mathrm{Fe}_{3} \mathrm{O}_{4}$. These iron oxides are associated with silicon, aluminum and calcareous vitreous during combustion to form bead-like or beadlike fine particles, so they are also called magnetic glass microspheres, which have advantages of strong magnetism, large specific surface area, low price and easy to obtain. If $\mathrm{BiVO}_{4}$ is compounded with magnetic glass microsphere, it could make $\mathrm{BiVO}_{4}$ materials magnetic and easier to separate in photocatalysis, and then improve the application of photocatalysis. In addition, it may promote the comprehensive utilization of fly ash, reduce the pollution of fly ash and achieve the purpose of treating waste with waste.

The preparation and synthesis of compound material (fly ash magnetic glass microsphere@ $\mathrm{BiVO}_{4}$, called as $\mathrm{FaBi}$ ) were reported in this paper. The properties of compound material were characterized by X-ray diffraction (XRD), Fourier transform infrared (FT-IR) spectroscopy, Scanning electron microscopy-energy dispersive spectroscopy (SEM), Magnetic hysteresis loop, X-ray photoelectron spectroscopy (XPS), UV-vis diffuse reflectance spectra and DFT calculation in order to prove its micro-structure and energy band structure. The photocatalytic efficiency of FaBi was studied by photocatalysis degradation experiments of Methylene Blue (MB) in solution. The impact factors in photocatalytic system, including reaction time and reaction kinetics, were also investigated. Moreover, to reveal the degradation mechanism, the adsorption effect of $\mathrm{FaBi}$ and negative influence of trapping agents on photocatalysis degradation experiments were conducted. Furthermore, the recycling usage of $\mathrm{FaBi}$ in photocatalytic system was discussed. 
The research proved that $\mathrm{FaBi}$ compound material showed excellent photocatalytic and adsorption activity for organic pollutant in solution. The magnetic separation properties make the material has great potentials for practical application of wastewater treatment.

\section{Materials and Experiments}

\section{Synthesis of Photocatalysts}

The magnetic glass microsphere (called Fa) was preliminarily selected from fly ash by magnet separation. The magnetic glass microspheres were put into a proper amount of DI water, cleaned by ultrasonic for $20 \mathrm{mins}$, and then precipitated. The precipitates were dried to constant weight under $80^{\circ} \mathrm{C}$.

$\mathrm{FaBi}$ was synthesized by hydrothermal method. Firstly, $30 \mathrm{mmol} \mathrm{NH}_{4} \mathrm{VO}_{3}$ and $30 \mathrm{mmol} \mathrm{Bi}\left(\mathrm{NO}_{3}\right)_{3} \cdot 5 \mathrm{H}_{2} \mathrm{O}$ were dissolved in $30 \mathrm{ml}$ nitric acid solution (3.5 mol/L). The solution $\mathrm{pH}$ was adjusted to 9 by $\mathrm{NaOH}$ aqueous solution. Secondly, both of $\mathrm{Fa}$ (the mass ratio with theoretical $\mathrm{BiVO}_{4}$ is 10:2) and the mixture solution above was put into a hydrothermal reactor $(100 \mathrm{ml})$. The hydrothermal reaction was carried out at KH-50 type hydrothermal synthesis reactor under $200^{\circ} \mathrm{C}$ for $7 \mathrm{~h}$. The outer shell of the hydrothermal reactor is made of stainless steel, and the inner lining is made of polytetrafluoroethylene, which is produced by Beijing Getimes Technology Co., Ltd. The reaction products were cooled to room temperature, and then washed with anhydrous alcohol and DI water. Finally, the synthetic product $(\mathrm{FaBi})$ was dried at electro-thermostatic blast oven to constant weight under $80^{\circ} \mathrm{C}$.

\section{Photocatalytic Experiments}

Photocatalytic experiments were carried out through degradation of Methylene blue (MB) under visible light irradiation (500W Xe-lamp). During each experiment, $0.025 \mathrm{~g}$ photocatalyst of $\mathrm{FaBi}$ was added into $50 \mathrm{ml} \mathrm{MB}$ or actual domestic wastewater solution (the concentration was $15 \mathrm{mg} / \mathrm{L}$ ). All experiments were conducted under room temperature, and the mixtures were put in a transparent photoreaction vessel. Before turning on the Xe lamp, the mixtures were kept under dark for 20 mins to promote the adsorption of MB on $\mathrm{FaBi}$. The photocatalytic reaction time ranges from 0 to 240 mins. After the reaction, the concentration of $\mathrm{MB}$ was determined by Ultraviolet visible spectrophotometer. In addition, different trapping agents including EDTA-2Na, TBA (tert-butyl alcohol), $\mathrm{BQ}$ (1,4-benzoquinone) and $\mathrm{CCl}_{4}$ were added to the reaction mixtures for studying the mechanism of photocatalytic degradation. For the reuse experiment of photocatalyst, FaBi was filtered out from the solution by $0.45 \mu \mathrm{m}$ filter membrane. The filer solids were washed by DI water for many times, and then dried at $80^{\circ} \mathrm{C}$.

\section{Adsorption Experiments}

The adsorption experiments were conducted in typical batch trials. In each adsorption trial, a quantity of $\mathrm{FaBi}(0.025 \mathrm{~g} / 25 \mathrm{ml})$ was dispersed in $\mathrm{MB}$ solution $(15 \mathrm{mg} / \mathrm{L})$ in a $50 \mathrm{~mL}$ Teflon bottle. The adsorption experiments were carried out under room temperature, the adsorption time ranged from 0 to $240 \mathrm{mins}$, and the $\mathrm{pH}$ of adsorption system was 6.7. Then, each bottle was fixed in a shaker machine, and stirred at a speed of $120 \mathrm{rpm} / \mathrm{min}$. After adsorption, each mixture was filtered through a $0.45 \mu \mathrm{m}$ membrane. The concentration of $\mathrm{MB}$ in filtered solution was determined by Ultraviolet visible spectrophotometer.

\section{Materials Characterization}

$\mathrm{Fa}$ and FaBi were characterized by X-ray diffraction, X-ray fluorescence, Scanning electron microscopyenergy dispersive spectroscopy, Fourier transform infrared spectroscopy, Microiontophoresis apparatus, X-ray photoelectron spectroscopy, UV-vis diffuse reflectance spectra, and the Magnetic hysteresis loop. X-ray fluorescence was analyzed by using ARL-9800 X-ray fluorescence analyzer from Swiss ARL. XRD patterns of powder samples were acquired using a Shimadzu XD-3A diffractometer, employing $\mathrm{Cu}-\mathrm{K} \alpha$ radiation $(\lambda=1.54056 \AA)$. The morphologies of the composites were observed with a HITACHI(S-3400N) scanning electron microscope and FT-IR spectra were recorded on a Nicolet iS5 FT-IR spectrometer using pressed $\mathrm{KBr}$ discs. The $\mathrm{X}$-ray photoelectron spectroscopy spectra were recorded on a PHI 5000 VersaProbe XPS equipment. The UV-vis spectrum research was carried out by PerkinElmer Ultraviolet spectrophotometer. The Magnetic hysteresis loop was studied by magnetic measuring instrument. The specific surface area was got from xigo liquid specific surface area analyzer.

\section{DFT Calculation}

The DFT calculation process was carried out through Vienna Ab initio Simulation Package (VASP) [22, 23] and spin-polarized Density Functional Theory (DFT) $[24,25]$. Perdew-Burke-Ernzerhof (PBE) functional within the generalized gradient approximation (GGA) $[26,27]$ method was used to calculate the exchangecorrelation potential. The cut-off energy for calculation is $450 \mathrm{eV}$. The K-points grids of dimensions were $5 \times 5 \times 5$. Both the atomic coordinates and cell parameters of $\mathrm{BiVO}_{4}$ were optimized. The theoretical $\mathrm{BiVO}_{4}$ model structure is a cell unit including $4 \mathrm{Bi}, 4 \mathrm{~V}$ and $16 \mathrm{O}$ atoms (Fig. 12a). 


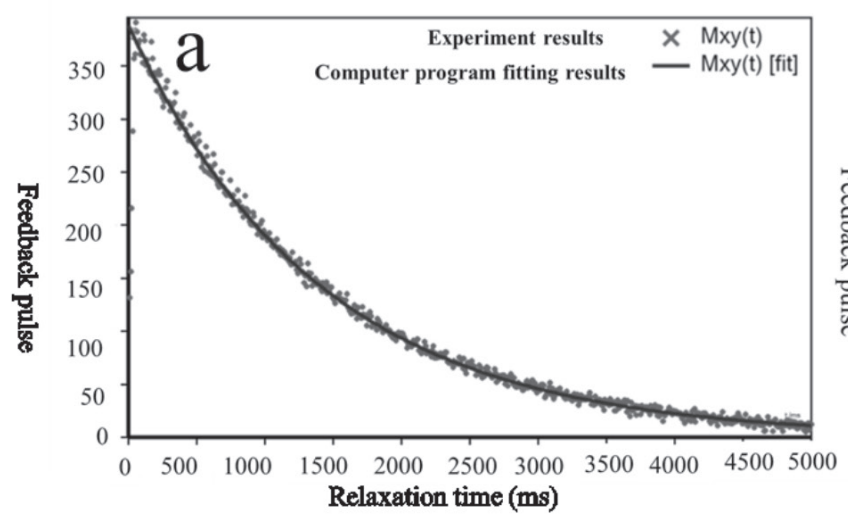

Fig. 1. Analysis results of liquid surface area.

\section{Results and Discussions}

\section{Specific Surface Area}

According to the analysis results of Xigo liquid specific surface area analyzer, the specific surface area of FA was $699 \mathrm{~m}^{2} / \mathrm{g}$, and the specific surface area of FaBi was $921.3 \mathrm{~m}^{2} / \mathrm{g}$, which indicated the loading process of $\mathrm{BiVO}_{4}$ increased the specific surface area of particles.

\section{$\mathrm{XRD}$}

Fig. 2 showed XRD patterns of Fa and FaBi. The magnetite, quartz and trace mullite were confirmed in Fig. 1 (blue line), since the peaks of $\mathrm{Fa}$ were in accordance with the standard peaks (PDF\#39-1346, PDF\#46-1045 and PDF\#15-0776). The absence of these three minerals in fly ash particles were commonly reported by related references $[28,29]$. Compared with Fig. 2, in the patterns of FaBi (red line), the strong peaks of $\mathrm{BiVO}_{4}$ (PDF\#14-0688 - Clinobisvanite) were observed and the peaks with less intensity of magnetite, quartz and mullite could also been found. These results

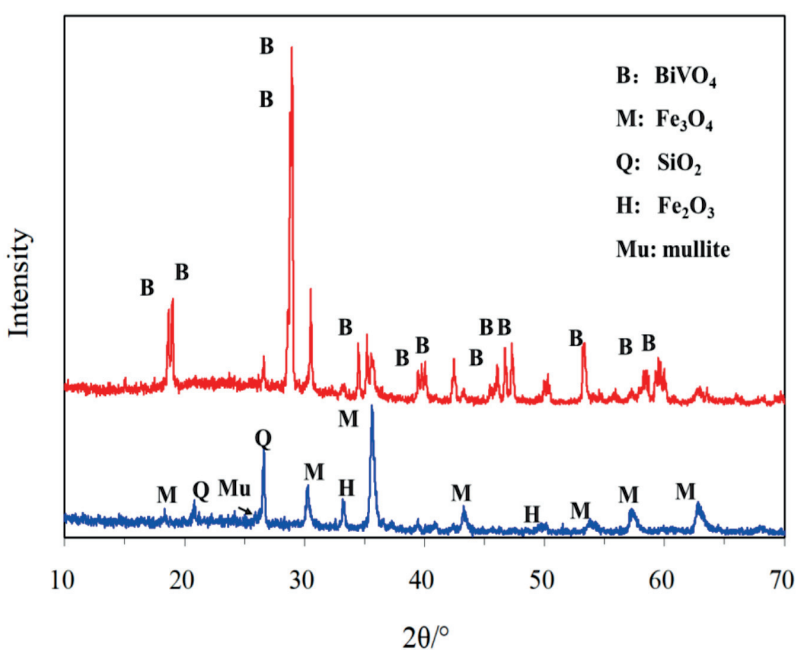

Fig. 2. XRD patterns of $\mathrm{FaBi}$ (red line) and $\mathrm{Fa}$ (blue line).

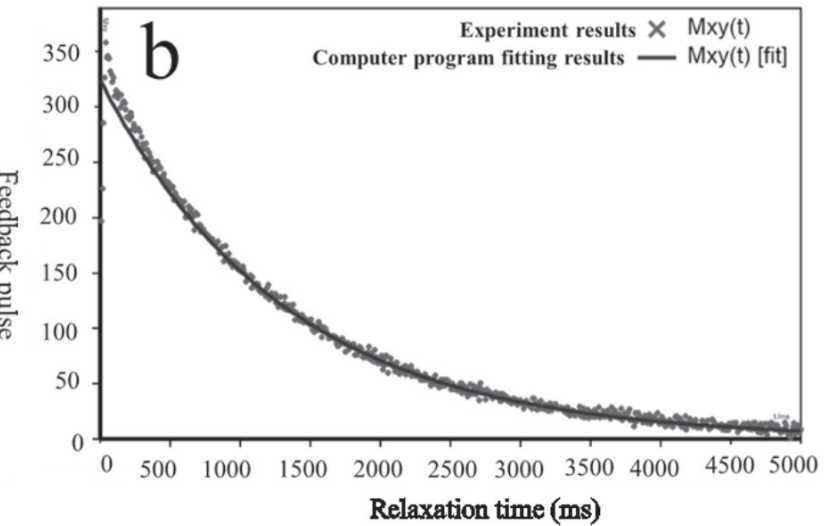

implied that $\mathrm{BiVO}_{4}$ minerals were successfully formed on the surface of Fa particles.

\section{FT-IR}

The properties of $\mathrm{Fa}, \mathrm{BiVO}_{4}$ and $\mathrm{FaBi}$ were further investigated by Fourier transform infrared spectroscopy, and the results were depicted in Fig. 3. For Fa (blue line), the peaks of $\mathrm{T}-\mathrm{O}$ bond (where $\mathrm{T}$ is $\mathrm{Si}$ or $\mathrm{Al}$ ) stretching bands could be found at around $1093 \mathrm{~cm}^{-1}$. The minor peaks observed at $789 \mathrm{~cm}^{-1}$ should be attributed to the double bands of quartz. In addition, two peaks at $585 \mathrm{~cm}^{-1}$ and $480 \mathrm{~cm}^{-1}$ should be assigned to the $\mathrm{O}-\mathrm{Si}(\mathrm{Al})-\mathrm{O}$ bending mode. The appearances of four characteristic peaks are very common in the infrared spectrum of fly ash particles [30, 31]. For $\mathrm{BiVO}_{4}$ (pink line), only one broad and strong absorption peak from 653 to $864 \mathrm{~cm}^{-1}$ was observed in FT-IR spectra, which was similar with the results of other researchers [32, 33]. For $\mathrm{FaBi}$ (red line), both the typical peaks of $\mathrm{Fa}$ (at $1108 \mathrm{~cm}^{-1}$ and $480 \mathrm{~cm}^{-1}$ ) and $\mathrm{BVO}_{4}$ (at $758 \mathrm{~cm}^{-1}$ ) appeared in the spectra. The results indicated that FaBi contained both $\mathrm{BiVO}_{4}$ and Fa. Besides, compared

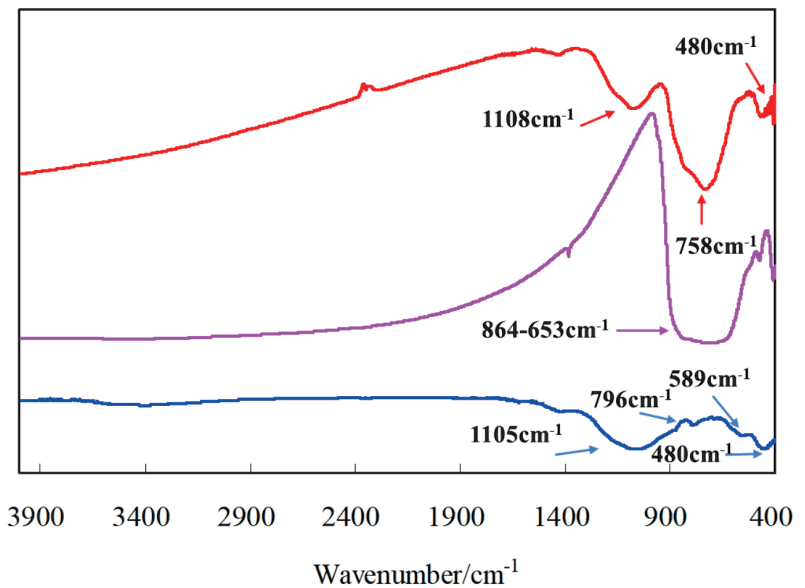

Fig. 3. FT-IR spectra of $\mathrm{FaBi}$ (red line), $\mathrm{BVO}_{4}$ (pink line) and $\mathrm{Fa}$ (blue line). 


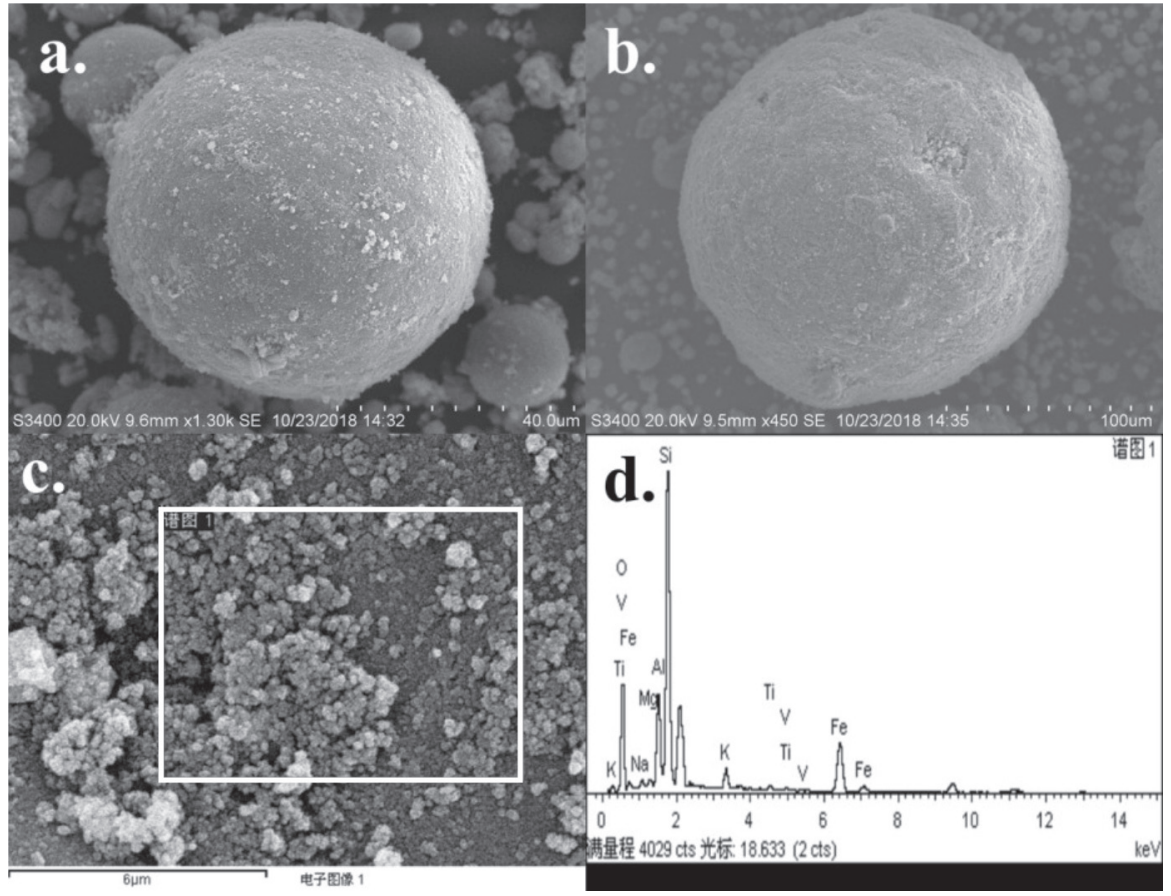

Fig. 4. The morphology (a and b) and EDX results (c and d ) of Fa.

with three spectra results of FT-IR, a little shift and deformation of typical infrared absorption peaks could be acceptable due to change of synthesis conditions.

\section{SEM}

The morphology and EDX results of $\mathrm{Fa}$ and $\mathrm{FaBi}$ were shown in Fig. 4 and Fig. 5. The magnetic glass microsphere (Fig. 4(a-b) was obtained after magnetic separation operation. The size of spherical particle was around $40 \mu \mathrm{m}$ to $100 \mu \mathrm{m}$, and the morphology of particle was similar with other researchers [34, 35]. In addition, Fig. 4a) and Fig. 4b) suggested that the magnetic glass microsphere had a smoother surface. Moreover, several amorphous particles were observed on the surface of microsphere with the expansion of magnification (Fig. 4c). The EDS analysis results revealed that the main compositions (atomic percent $/ \%$ ) of microsphere

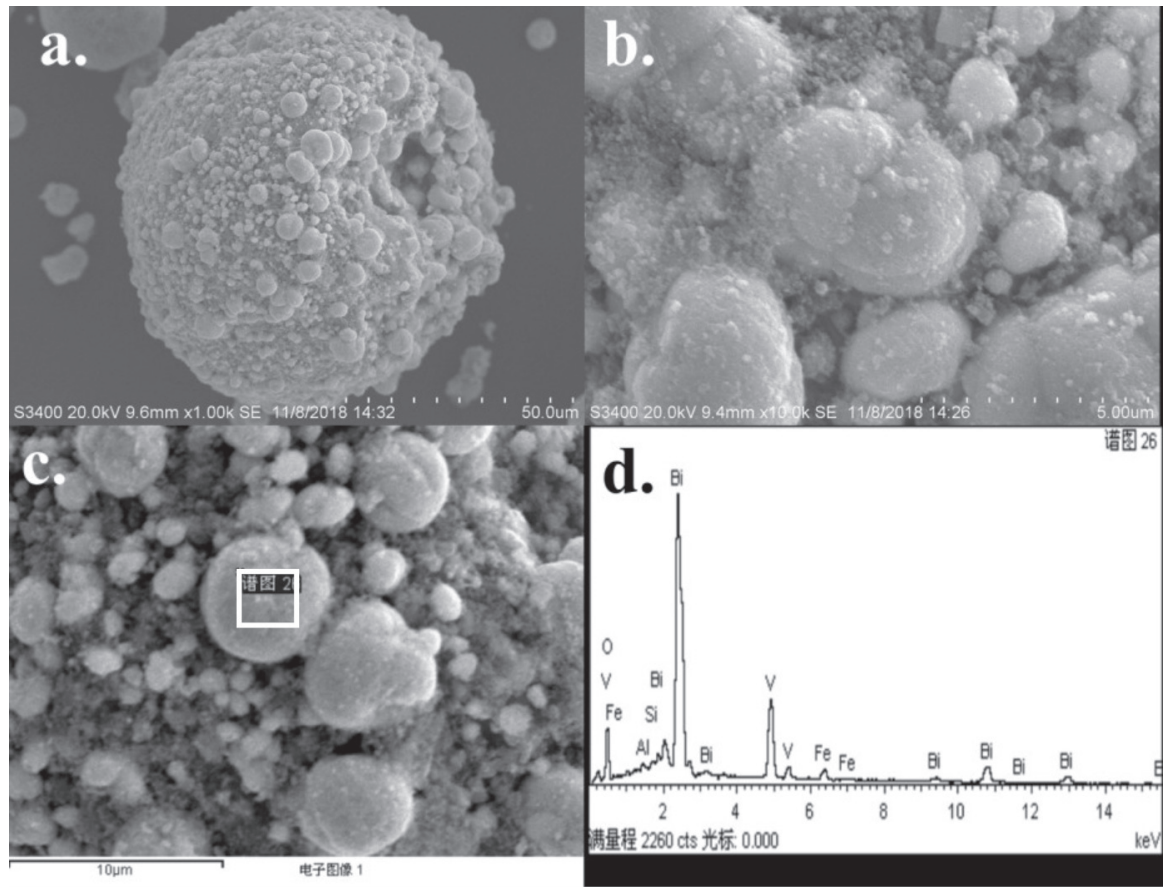

Fig. 5. The morphology (a and b) and EDX results (c and d ) of FaBi. 


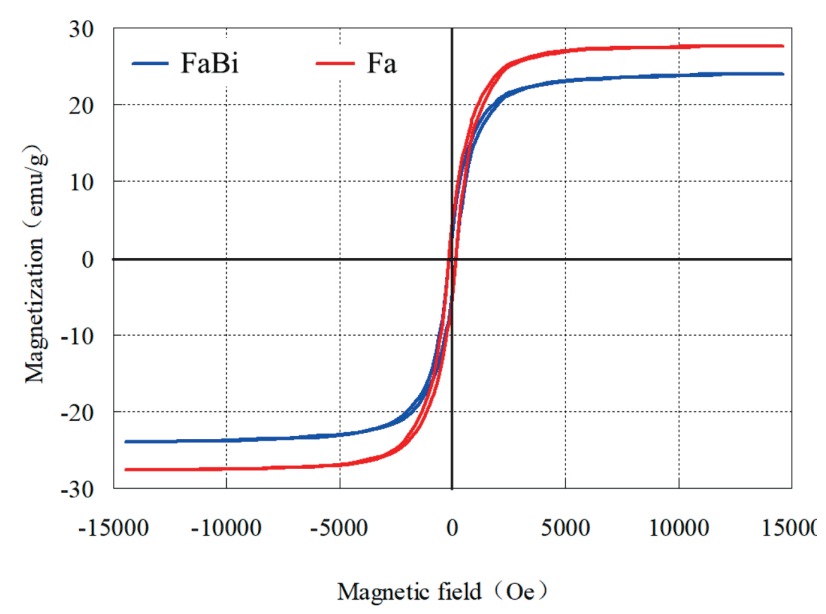

Fig. 6. The Magnetic Hysteresis loop of Fa and FaBi.

surface were $7.7 \% \mathrm{Al}, 31.78 \% \mathrm{Si}, 19.23 \% \mathrm{Fe}, 35.77 \% \mathrm{O}$ and others. Furthermore, according to related references $[36,37]$ and the results of XRD/FT-IR, these irregular particles should be a mixture of hematite, quartz and fly ash glass components. After the synthesis reaction, the spherical particle became slightly irregular (Fig. 5a) and the surface was surrounded by abundant small spheroid like particles $(2-4 \mu \mathrm{m})$. Also, with the help of EDS analysis, we learned that the main composition (atomic percent/\%) of spheroid like particles were $13.89 \% \mathrm{~V}, 62.36 \% \mathrm{Bi}, 0.32 \% \mathrm{Al}, 0.56 \%$
Si, 20.72\% O and others. According to the EDS analysis and previous XRD/FT-IR analysis, we believed the spheroid like particles must be $\mathrm{BiVO}_{4}$, and it successfully deposited on the surface of Fa particles.

\section{Magnetic Hysteresis Loop}

The vibrating sample magnetometer was used for investigating the magnetic behaviors of $\mathrm{Fa}$ and FaBi. The results were shown in Fig. 6. Both Fa and FaBi showed "S-shaped" magnetization curves and the saturation magnetization of $\mathrm{Fa}$ and $\mathrm{FaBi}$ was $23.95 \mathrm{emu} / \mathrm{g}$ and $27.52 \mathrm{emu} / \mathrm{g}$, respectively. According to references [38, 39], these saturation magnetization results could give $\mathrm{Fa}$ and $\mathrm{FaBi}$ sufficient magnetism for efficient magnetic separation from aqueous solution. Besides, the coercivities of $\mathrm{Fa}$ and $\mathrm{FaBi}$ was around -70.10 e and $-69.2 \mathrm{Oe}$, respectively, which suggested that $\mathrm{Fa}$ and $\mathrm{FaBi}$ had weak residual magnetism.

\section{XPS}

The surface chemical composition of $\mathrm{FaBi}$ and $\mathrm{Fa}$ were further investigated by XPS, and the results were shown in Fig. 7, which indicated the main peaks of Fa were C1s $(283 \mathrm{eV}), \mathrm{O} 1 \mathrm{~s}(531 \mathrm{eV}), \mathrm{Al} 2 \mathrm{p}(73 \mathrm{eV}), \mathrm{Si} 2 \mathrm{p}$ $(100 \mathrm{eV}), \mathrm{Al} 2 \mathrm{~s}(118 \mathrm{eV}), \mathrm{Si} 2 \mathrm{~s}(149 \mathrm{eV})$ and Fe2p $(710 \mathrm{eV})$. Except for carbon (testing needs), the other elements were commonly found in Fly ash particles and in accord
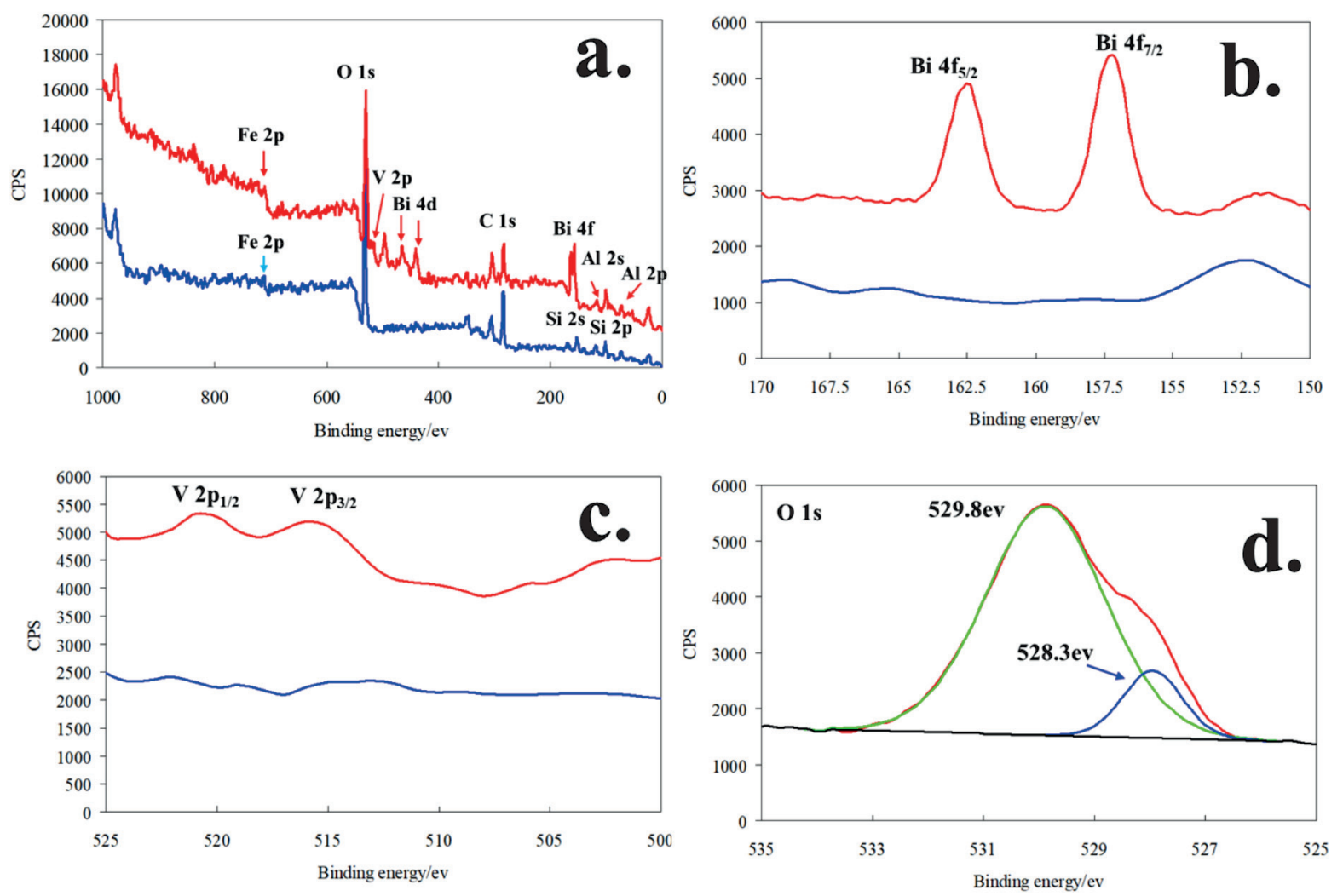

Fig. 7. a) the wide scan XPS spectra a) of FaBi (red line) and Fa (blue line); the high-resolution XPS spectra of FaBi(red line) and Fa (blue line), b) Bi4f; c) V2p; d) O1s (only FaBi). 
with the results of other characterization methods. The Fe2p peaks at around $710 \mathrm{eV}$ suggested the spinorbit peaks of $\mathrm{Fe}_{3} \mathrm{O}_{4}$ [40]. Compared with $\mathrm{Fa}$, the XPS of FaBi presented obviously new Bi4f peaks $(157 \mathrm{eV}$ and $162 \mathrm{eV})$, Bi4d peaks $(440 \mathrm{eV}$ and $463 \mathrm{eV})$ and $\mathrm{V} 2 \mathrm{p}$ $(515 \mathrm{eV}$ and $521 \mathrm{eV})$. More details could be found from the high-resolution XPS spectra of B/MGM at Bi4f (Fig. 5b) and V2p (Fig. 5c). Fig. 5b) suggested that the two new Bi4f peaks at $162 \mathrm{eV}$ and $157 \mathrm{eV}$ were corresponded to $\mathrm{Bi}_{4} \mathrm{f}_{5 / 2}$ and $\mathrm{Bi}_{4} \mathrm{f}_{7 / 2}$. The two peaks should originate from the characteristic of $\mathrm{Bi}^{3+}$ cations with a $5.3 \mathrm{eV}$ spin orbit splitting in $\mathrm{BiVO}_{4}$ molecules [41]. Fig. 5c) showed the high-resolution XPS spectra of B/MGM at V2p. From Fig. 5c), and the two new V2p peaks at $515 \mathrm{eV}$ and $521 \mathrm{eV}$ were belonged to $\mathrm{V} 2 \mathrm{p}_{3 / 2}$ and $\mathrm{V} 2 \mathrm{p}_{1 / 2}$. The two peaks proved that the existing of $\mathrm{V}^{5+}$ cations in the $\mathrm{BiVO}_{4}$ lattice sites [42]. Fig. 5d) presented the high-resolution XPS spectra of $\mathrm{FaBi}$ at O1s. In Fig. $5 \mathrm{c}$ ), there were two different types of oxygen in O1s peaks including $529.8 \mathrm{eV}$ and $528.3 \mathrm{eV}$. As we know, the two O1s peaks should be attributed to the oxygen in $\mathrm{BiVO}_{4}$ molecules and $\mathrm{Fa}$ particles phase. It is worth noting that $\mathrm{BiVO}_{4}$ has been successfully coated on the surface of MGM particles.

\section{UV-Vis Diffuse Reflectance Spectra}

Fig. 8a) presented the UV-vis diffuse reflectance spectra of $\mathrm{BiVO}_{4}$ and $\mathrm{FaBi}$. For $\mathrm{BiVO}_{4}$, a strong and broad absorption band between around $300 \mathrm{~nm}$ and $540 \mathrm{~nm}$ could be observed. According to references [41], the adsorption band should be explained by the intrinsic band gap absorption. Moreover, the UV-vis diffuse reflectance spectra of $\mathrm{FaBi}$ was strengthened in the range of $460 \mathrm{~nm}$ to $800 \mathrm{~nm}$, and the adsorption edges moved towards the direction of high wavelength. The change of spectrum was mainly due to the narrower band gap $(0.1 \mathrm{eV})$ of $\mathrm{Fe}_{3} \mathrm{O}_{4}$ crystal on the surface of MGM particles and would directly lead to the increase of light utilization efficiency

Tauc equation (as bellow) is often used to calculate the band gap energy.
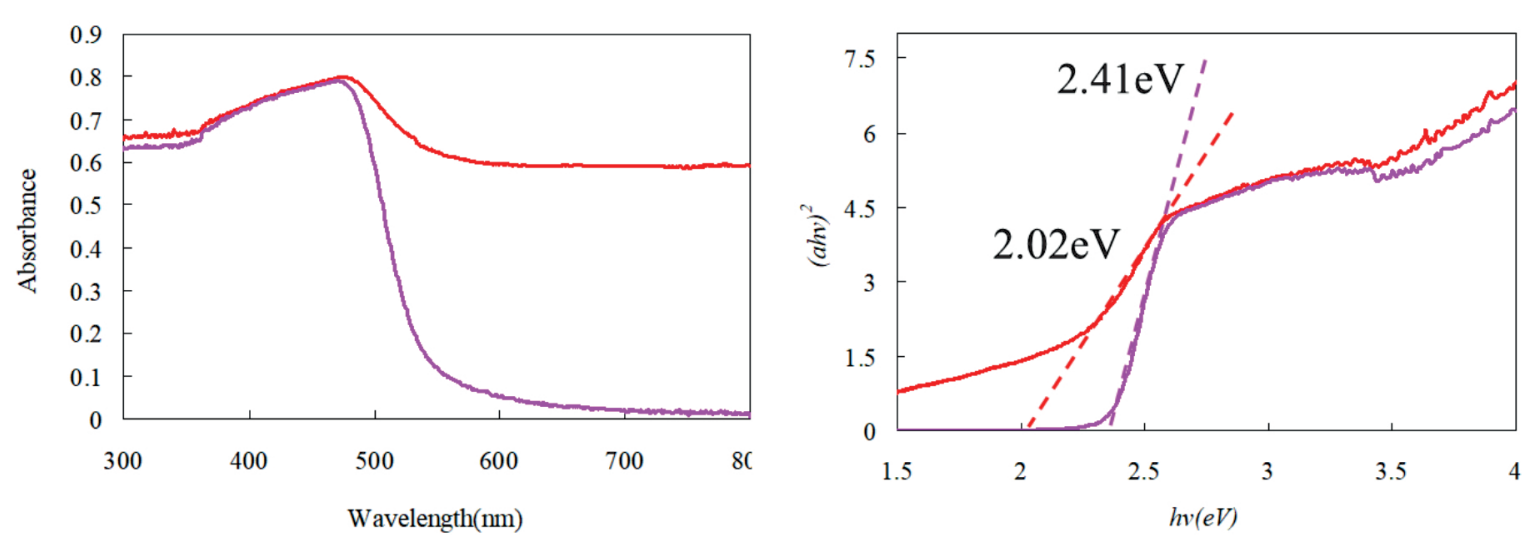

...where, $\alpha, \mathrm{h}, \mathrm{v}, \mathrm{A}$ and $\mathrm{Eg}$ represents absorption coefficient at light frequency $v$, Planck constant, light frequency, a constant and band gap energy, respectively. For direct transition semiconductor as $\mathrm{BiVO}_{4}$, the value of $\mathrm{n}$ is 1 .

According to Tauc equation, the value of Eg could be obtained through plotting the curve of $[a(v) h v]^{2}$ versus $h v$ and extra-polating the linear part of the curve to zero absorption coefficient. The analysis process was carried out and the results were shown in Fig. 8b). The band gap energy of $\mathrm{BiVO}_{4}$ was $2.41 \mathrm{eV}$, which was very close to the results of referenced bibliography [41]. For $\mathrm{FaBi}$, the band gap energy decreased to $2.02 \mathrm{eV}$, which might increase the activity of visible light catalysis

\section{Photocatalytic Activity}

In experiments, $\mathrm{MB}$ was used as the research object to study the photocatalytic activity of catalyst. And then the apparent degradation kinetics was investigated through first-order reaction model. The equation of the first-order reaction model is as follows. The reaction constant $\mathrm{k}$ can be obtained by fitting the equation (2) and the experimental results.

$$
\operatorname{Ln}\left(\frac{C}{C_{0}}\right)=-k t
$$

...where, $\mathrm{C}_{0}$ represents the initial concentration of $\mathrm{MB}$ and $\mathrm{C}_{\mathrm{t}}$ represents the concentration of $\mathrm{MB}$ at time $\mathrm{t}$.

Preliminary experiments showed that, there was no obvious degradation of MB under only light (no catalyst) and only catalyst (no light) system. Fig. 9a) indicated the results of photocatalytic degradation of MB. The Xe lamp was turn on at $0 \mathrm{~min}$, and the stage between -20 to 0 min promoted the adsorption of $\mathrm{MB}$ on catalyst. Firstly, from Fig. 9a), the degradation effect of $\mathrm{MB}$ under $\mathrm{FaBi}$ and pure $\mathrm{BiVO}_{4}$ photocatalytic systems

Fig. 8. UV-vis diffuse reflectance spectra of $\mathrm{BiVO}_{4}$ and $\mathrm{FaBi}$. 
was better than that of pure Fa system, which suggested that the composite of $\mathrm{BiVO}_{4}$ on the surface of magnetic glass microsphere could make the material have obvious photocatalytic activity. Secondly, compared with the system of pure $\mathrm{BiVO}_{4}$ catalyst, FaBi system presented better photocatalytic performance. The residual rate of $\mathrm{MB}$ was $54 \%$ at $20 \mathrm{mins}$, and the residual rate of target pollutant was only $1.5 \%$ at 240 mins, which was higher than that of pure $\mathrm{BiVO}_{4}$ system. The reasons
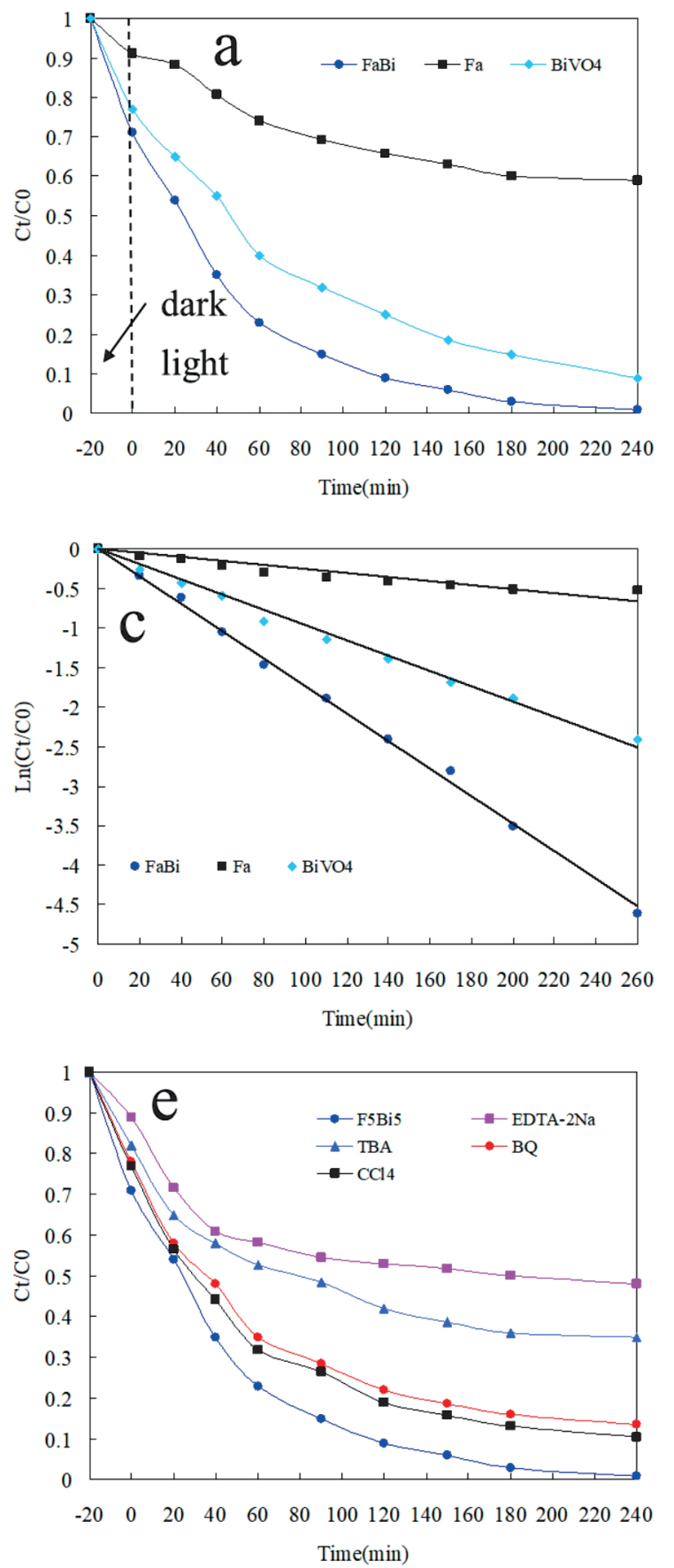

should be attributed to the large specific surface area $\left(921.3 \mathrm{~m}^{2} / \mathrm{g}\right)$ of magnetic glass microsphere. The large specific surface area supplied sufficient reaction site for the contact among $\mathrm{BiVO}_{4}$, pollutants and light. The change of UV-visible absorption spectrum of $\mathrm{MB}$ with reaction time was shown in Fig. 9b). Fig. 9b) suggested that peaks of MB gradually decreased with reaction time, which indicated that $\mathrm{MB}$ was photodegraded by FaBi. Fig. 9c) presented the results of
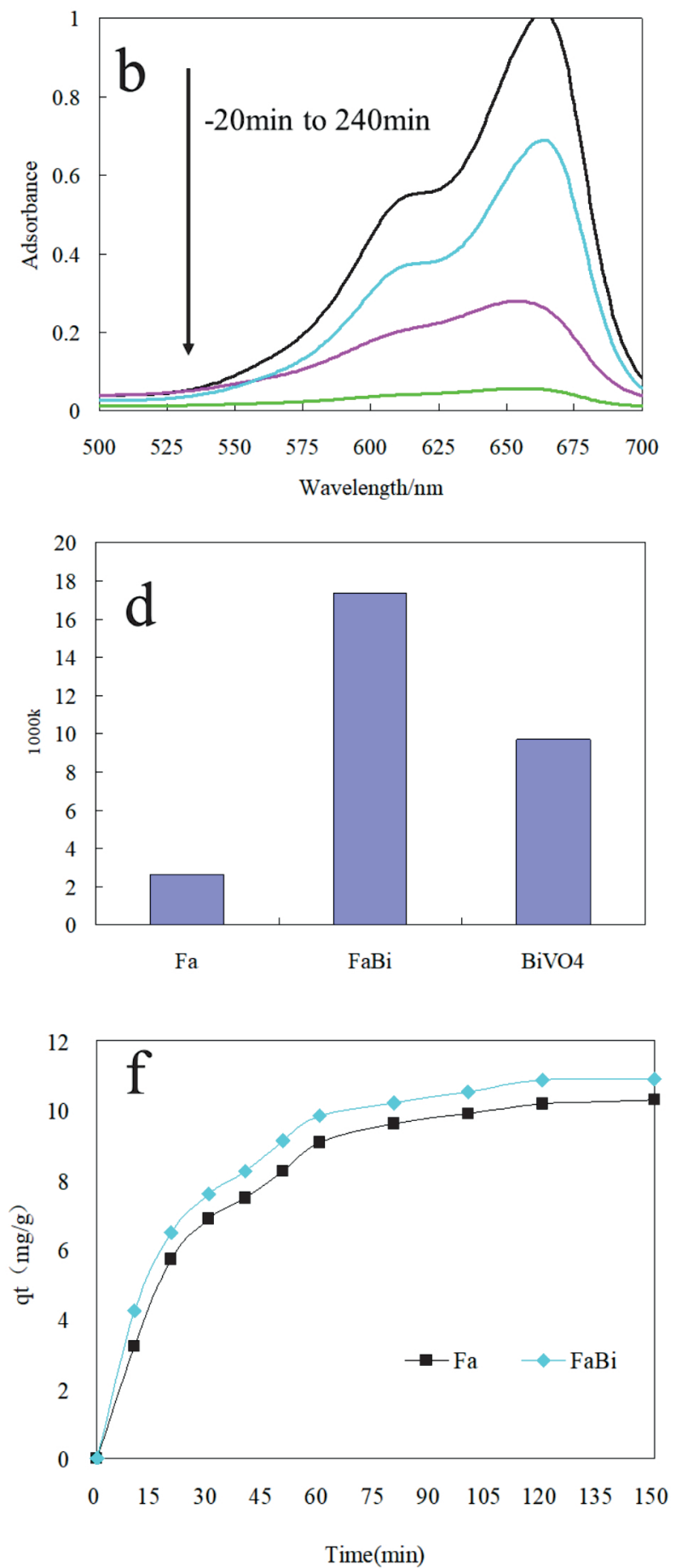

Fig. 9. a) Photodegradation process of $\mathrm{MB}$ by $\mathrm{Fa}, \mathrm{BiVO}_{4}$ and $\mathrm{FaBi}$; b) UV-visible absorption spectrum of the MB solution degrated by $\mathrm{FaBi}$; c) the apparent fitting results using the pseudo-first-order reactions; d) the constants of the first-order reactions for the $\mathrm{MB}$ photodegradation; e) effect of different trapping agents on the photocatalytic activity of FaBi f)adsorption results of $\mathrm{MB}$ on $\mathrm{Fa}$ and $\mathrm{FaBi}$. 
apparent kinetics fitting results using equation (2) (based on the data in Fig. 9a). The $\mathrm{R}^{2}$ values of FaBi and pure $\mathrm{BiVO}_{4}$ system were all above 0.99 , which suggested the apparent photocatalytic degradation process could be satisfactorily fitted by first-order reaction model. The $\mathrm{R}^{2}$ values of Fa system was only 0.85 , which implied that the degradation mechanism of $\mathrm{MB}$ was different in $\mathrm{Fa}$ system. Moreover, from Fig. 9d), the $\mathrm{k}$ value of $\mathrm{FaBi}$ (0.0174) system was the largest, which was higher than that of other systems, and the results were similar with that of Fig. 9a) and 9c).

$$
\mathrm{O}_{2}+e^{-} \rightarrow \cdot \mathrm{O}_{2}^{-}
$$

$$
\cdot \mathrm{O}_{2}^{-}+\mathrm{MB} \rightarrow \text { Degradation - products }
$$

$$
\mathrm{H}_{2} \mathrm{O} / \mathrm{OH}^{-}+h^{+} \rightarrow \cdot \mathrm{OH}^{-}
$$

$$
\cdot \mathrm{OH}+\mathrm{MB} \rightarrow \text { Degradation - products }
$$

As we know, the photocatalytic process mainly depends on the strong redox of free electrons, holes and related free radicals released by photocatalytic catalysts. Fig. 9e) stated the effect of different trapping agents on the photocatalytic activity of FaBi. According to the related literatures [43, 44], EDTA-2Na was a hole trapper, TBA was a hydroxyl radical trapper, BQ was an oxygen free radical trapper, and $\mathrm{CCl}_{4}$ was an electron trapper. The photocatalytic activity of $\mathrm{FaBi}$ decreased in all trapping agent systems in Fig. 9e) which indicated the degradation path as equation (3) to (5) might happen during the photocatalytic degradation process of MB. Among them, EDTA-2Na and TBA displayed greater impact on the photocatalytic degradation of MB. In 60mins, the residual rate of nontrapping agent system was $35 \%$, while that of $58.2 \%$ and $52.7 \%$ in EDTA-2Na and TBA system, respectively. In $180 \mathrm{mins}$, the residual rate of non-trapping agent was only $6 \%$, while that of $50.1 \%$ and $36.1 \%$ in EDTA-2Na and TBA system, respectively. The results indicated that the capture of holes and hydroxyl radicals might seriously affect the photodegradation activity, which could be explained that the main degradation path of MB should be as equation (3) to (6).

The pseudo-first-order model for adsorption [45];

$$
\operatorname{Ln}\left(q_{\mathrm{e}-\mathrm{exp}}-q_{\mathrm{t}}\right)=\operatorname{Ln}\left(q_{\mathrm{e}-\mathrm{cal}}\right)-k_{1} t
$$

...where, $\mathrm{q}_{\mathrm{t}}(\mathrm{mg} / \mathrm{g})$ is the mass of MB adsorbed per unit mass of $\mathrm{Fa}$ and FaBi. $\mathrm{q}_{\mathrm{e}-\mathrm{exp}}(\mathrm{mg} / \mathrm{g})$ and $\mathrm{q}_{\mathrm{e}-\text { cal }}(\mathrm{mg} / \mathrm{g})$ are the mass of $\mathrm{MB}$ adsorbed per unit mass of $\mathrm{Fa}$ and $\mathrm{FaBi}$ at adsorption equilibrium obtained from experimental work and model calculations. $\mathrm{k}_{1}\left(\mathrm{~min}^{-1}\right)$ is the rate constant of first-order model.

The pseudo-second-order model [46];

$$
\frac{t}{q_{\mathrm{t}}}=\frac{1}{k_{2} q_{\mathrm{e}-c a l}^{2}}+\frac{t}{q_{\mathrm{e}-\mathrm{cal}}}
$$

...where, $\mathrm{k}_{2}\left(\mathrm{~g} \cdot \mathrm{mg}^{-1} \cdot \mathrm{min}^{-1}\right)$ is the rate constant of the second-order model.

The equation of Langmuir isotherm is as follows [47];

$$
\frac{C_{e}}{q_{e}}=\frac{1}{k_{L} q_{m}}+\frac{C_{e}}{q_{m}}
$$

...where $\mathrm{q}_{\mathrm{e}}$ and $\mathrm{C}_{\mathrm{e}}$ are the amount adsorbed $(\mathrm{mg} / \mathrm{g})$ and $\mathrm{MB}$ concentration on solution $(\mathrm{mg} / \mathrm{L})$, both at equilibrium; $\mathrm{k}_{\mathrm{L}}(\mathrm{L} / \mathrm{mg})$ is the Langmuir constant related to the energy of adsorption; and $\mathrm{q}_{\mathrm{m}}(\mathrm{mg} / \mathrm{g})$ is the maximum adsorption capacity.

The equation of Freundlich isotherm is as follow [48];

$$
\operatorname{Ln}\left(\mathrm{q}_{\mathrm{e}}\right)=\operatorname{Ln}\left(\mathrm{k}_{\mathrm{F}}\right)+\frac{1}{n} \operatorname{Ln}\left(\mathrm{C}_{\mathrm{e}}\right)
$$

...where, $\mathrm{k}_{\mathrm{F}}$ and $\mathrm{n}$ are constants for Freundlich isotherm, and they are indicative of the adsorption capacity $(\mathrm{mg} / \mathrm{g})$ and adsorption intensity.

According to previous research and literature [33], if the catalyst had obvious adsorption effect on pollutants, it would greatly improve the photocatalytic activity. Fig. 9f) depicted the adsorption results of $\mathrm{MB}$ on $\mathrm{Fa}$ and $\mathrm{FaBi}$. It can be verified both $\mathrm{Fa}$ and $\mathrm{FaBi}$ had adsorption capacity for MB. The adsorption quantity of $\mathrm{FaBi}$ was $4.5 \mathrm{mg} / \mathrm{g}$ at $20 \mathrm{mins}$ and $11.1 \mathrm{mg} / \mathrm{g}$ at $150 \mathrm{mins}$, respectively, which was a little higher than that of $\mathrm{Fa}$. The adsorption quantity of $\mathrm{Fa}$ was $3.5 \mathrm{mg} / \mathrm{g}$ in $20 \mathrm{mins}$ and $10.5 \mathrm{mg} / \mathrm{g}$ in $150 \mathrm{mins}$,

\begin{tabular}{|c|c|c|c|c|c|c|c|}
\hline & \multirow{2}{*}{$\underset{(\mathrm{mg} / \mathrm{g})}{\mathrm{q}_{\exp }}$} & \multicolumn{3}{|c|}{ Pseudo-first-order } & \multicolumn{3}{|c|}{ Pseudo-second-order } \\
\hline & & $\mathrm{k}_{1}(/ \min )$ & $\mathrm{q}_{\text {cal }}(\mathrm{mg} / \mathrm{g})$ & $\mathrm{R}^{2}$ & $\mathrm{k}_{2}(\mathrm{~g} / \mathrm{mg} \cdot \mathrm{min})$ & $\mathrm{q}_{\mathrm{cal}}(\mathrm{mg} / \mathrm{g})$ & $\mathrm{R}^{2}$ \\
\hline $\mathrm{Fa}$ & 10.3 & 0.0229 & 12.38 & 0.9742 & 12.10 & 0.00355 & 0.9965 \\
\hline $\mathrm{FaBi}$ & 11.1 & 0.0262 & 8.72 & 0.9872 & 12.39 & 0.00441 & 0.9989 \\
\hline
\end{tabular}
respectively. The adsorption capacity of Fa should be attributed to the properties of its particle surface [49, 50]. The synthesis process of catalyst might make its surface adsorption capacity slightly improved. Table 1 showed the adsorption kinetics and adsorption isotherm of $\mathrm{MB}$ on $\mathrm{Fa}$ and $\mathrm{FaBi}$. The $\mathrm{R}^{2}$ values obtained by

Table1. Pseudo-first-order and pseudo-second-order rate constants calculated from experiment data. 
Table 2. Adsorption isotherms constants calculated from the experiment data.

\begin{tabular}{|c|c|c|c|c|c|c|}
\hline \multicolumn{5}{|c|}{ Langmuir } & \multicolumn{3}{c|}{ Freundlich } \\
\hline & $\mathrm{q}_{\mathrm{m}}(\mathrm{mg} / \mathrm{g})$ & $\mathrm{k}_{\mathrm{L}}(\mathrm{L} / \mathrm{mg})$ & $\mathrm{R}^{2}$ & $\mathrm{k}_{\mathrm{f}}$ & $\mathrm{n}$ & $\mathrm{R}^{2}$ \\
\hline $\mathrm{Fa}$ & 19.49 & 0.109 & 0.9946 & 2.67 & 1.783 & 0.9834 \\
\hline $\mathrm{FaBi}$ & 20.61 & 0.147 & 0.9932 & 3.688 & 1.982 & 0.9880 \\
\hline
\end{tabular}

the quasi-second-order model were larger than that of quasi-first-order model. The $\mathrm{q}_{\mathrm{e}-\mathrm{cal}}$ value calculated from pseudo-second-order model was more consistent with the experimental $\mathrm{q}_{\mathrm{e} \text {-exp }}$ value. Therefore, the pseudosecond-order kinetic equation was more suitable to describe the adsorption behavior of $\mathrm{MB}$ on $\mathrm{Fa}$ and FaBi. Furthermore, Table 2 expressed the $\mathrm{R}^{2}$ values of Langmuir adsorption isotherm was more close to 1 than that of Freundlich adsorption isotherms, which indicated Langmuir adsorption isotherm was better to depict the adsorption process of $\mathrm{MB}$ on $\mathrm{Fa}$ and $\mathrm{FaBi}$.

\section{Catalysts Recycling}

Fig. 10a) showed the morphology of FaBi after $3^{\text {rd }}$ photocatalysis experiment. Compared with Fig. 4a), there were no obvious changes in the overall appearance of FaBi particles, and only particles on the surface were slightly reduced. The reasons could be explained as the spalling of a little $\mathrm{BiVO}_{4}$ during the photocatalysis experiment. Fig. 10b) depicted XRD patterns of FaBi after $3^{\text {rd }}$ photocatalysis experiment. In contrast with the previous results, there was also no clear change in
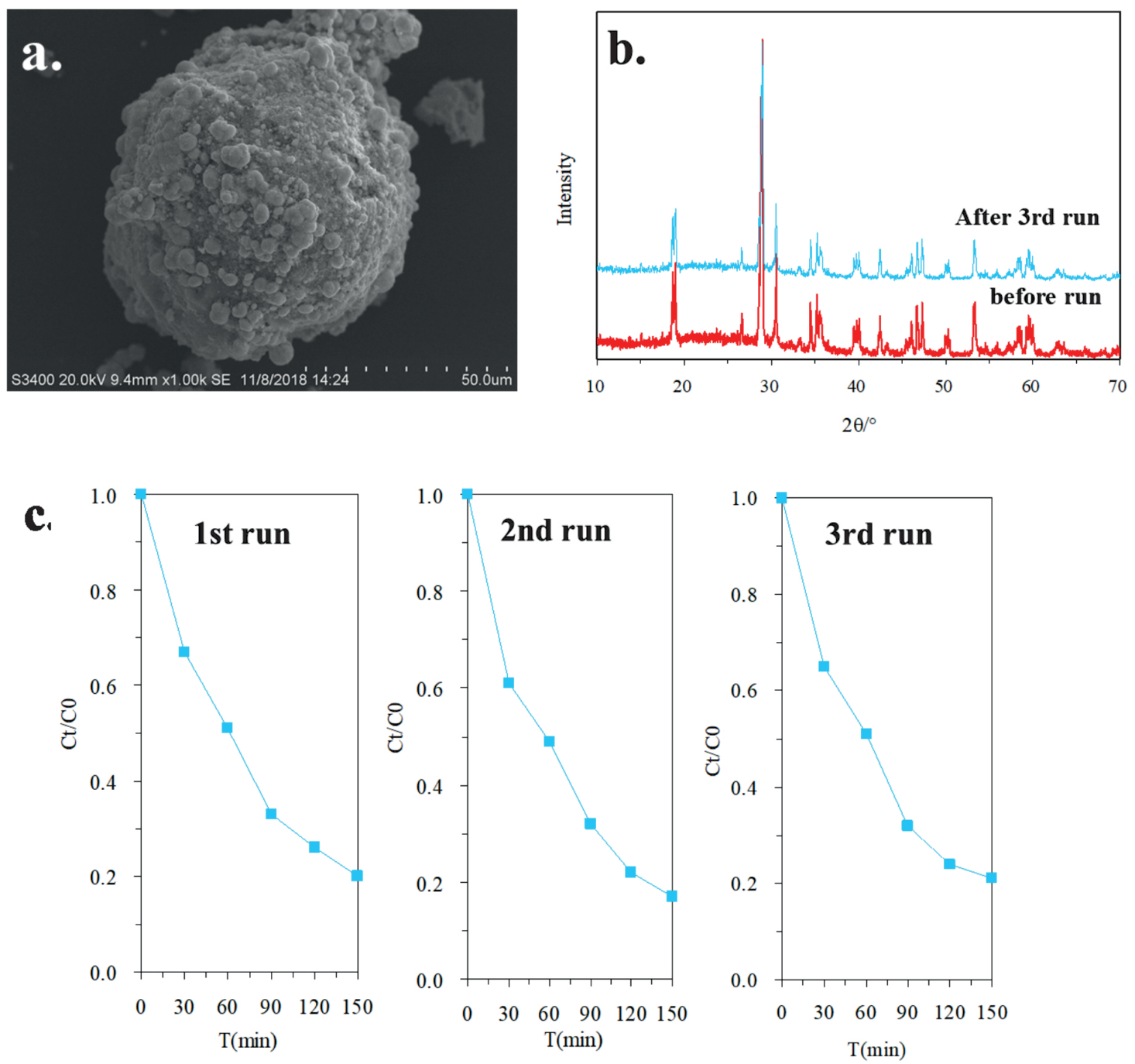

Fig. 10. a) The morphology of FaBi after $3^{\text {rd }}$ photocatalysis experiment; b) The XRD patterns of FaBi before and after $3^{\text {rd }}$ photocatalysis experiment; c) Degradation curve of FaBi reuse. 

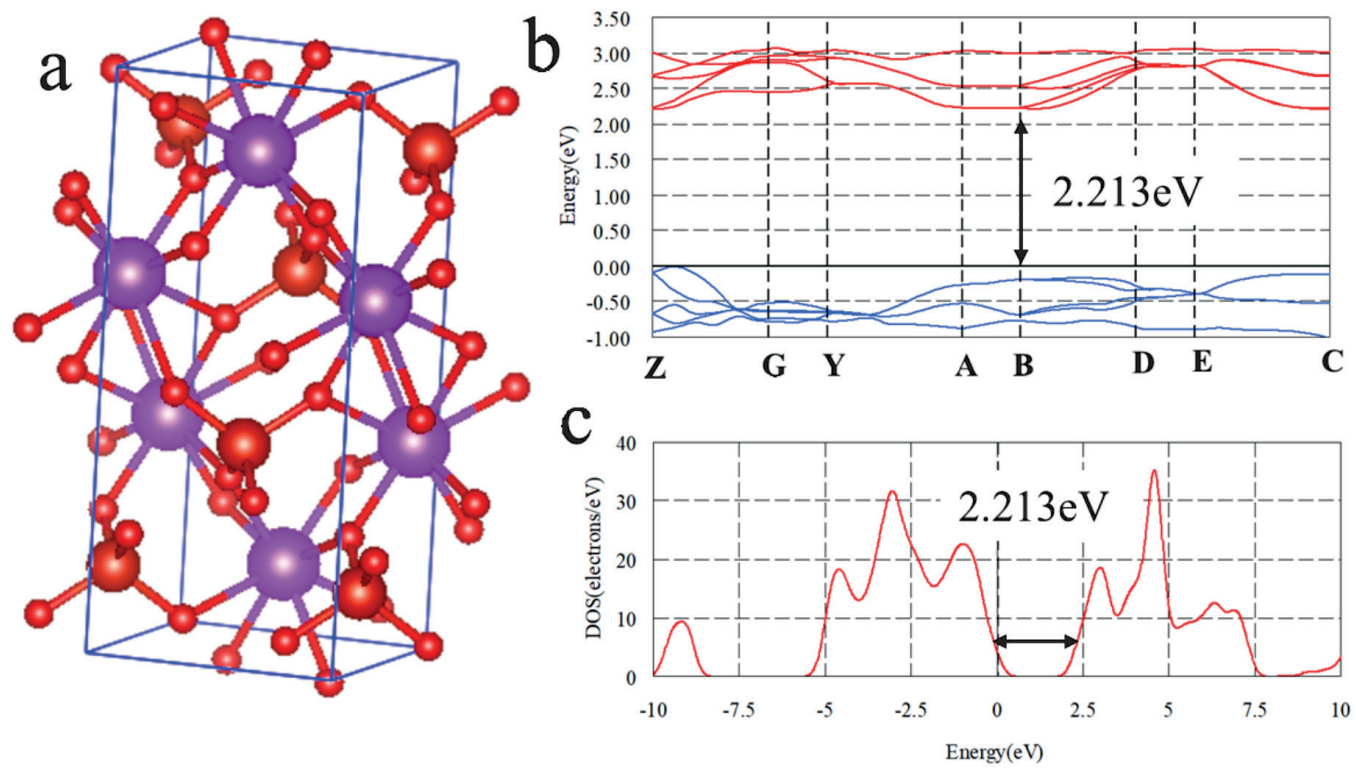

Fig. 11. a) Crystal structure of $\mathrm{BiVO}_{4}$ (Purple ball: Bi atom; bigger read ball: V atom; smaller reder ball: o atom); b) and c) band structure and $\mathrm{DOS}$ of $\mathrm{BiVO}_{4}$ gained from DFT calculation.

the peak position, which suggested there was no phase change reaction during the photocatalysis experiment. In addition, the peak intensities of $\mathrm{BiVO}_{4}$ became a little weaker after $3^{\text {rd }}$ photocatalysis experiment, which should also be resulted from the loss of $\mathrm{BiVO}_{4}$ during the experiment. Besides, the stability and reuse efficiency was shown in Fig. 10c). It indicated no notable attenuation of photocatalysis activity could be found after three reuse cycles. The FaBi composite possessed good photocatalyst stability, and the photo corroded in the photo degradation process could be accepted.

\section{Degradation Mechanism}

Fig. 11 presented the crystal structure of $\mathrm{BiVO}_{4}$, band structure and Density of States (DOS) of $\mathrm{BiVO}_{4}$

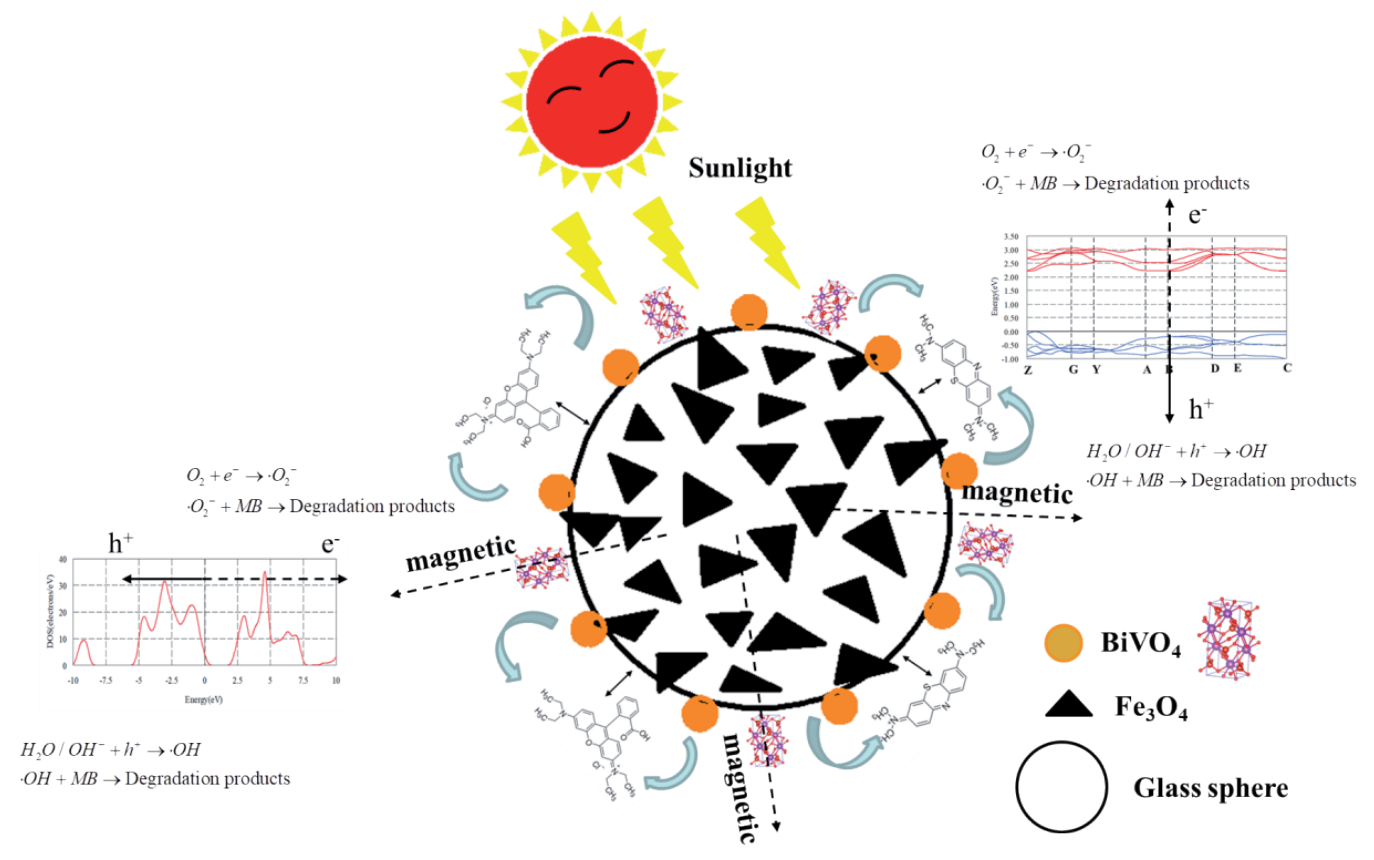

$\mathrm{H}_{2} \mathrm{O} / \mathrm{OH}^{-}+h^{+} \rightarrow \cdot \mathrm{OH}$

$\mathrm{OH}+\mathrm{Rhb} \rightarrow$ Degradation products

Fig. 12. Mechanism of photocatalytic degradation. 
gained from DFT calculation. The band gap was $2.213 \mathrm{eV}$, which was smaller than the results obtained from experiments (Fig. 6). This small difference was widely interpreted as the inherent weakness of DFT calculation. Such band gap made $\mathrm{BiVO}_{4}$ very sensitive to visible light, which could produce free electrons and free holes under the irradiation of visible light.

Based on our previous results, we can summarize the mechanism of $\mathrm{MB}$ photocatalysis degradation by Fabi as follows (Fig. 12): (1) the adsorption ability of $\mathrm{FaBi}$ particles can adsorb $\mathrm{MB}$ from solution to the surface of FaBi particles. (2) Because the band gap is very suitable, under the excitation of visible light, the electrons in $\mathrm{BiVO}_{4}$ valence band are excited to the conduction band, which lead to free electrons generated in conduction band, and free holes generated in valence band. (3) Free electrons and free holes (main function) on the surface of $\mathrm{BiVO}_{4}$ can degrade $\mathrm{MB}$ (adsorbed) by direct redox reaction and indirect free radical reaction. (4) The adsorption ability of FaBi particles can greatly promote the photocatalytic degradation. (5) $\mathrm{Fe}_{3} \mathrm{O}_{4}$ (mixed with the glass sphere) makes the particles have favorable ferromagnetism, which makes it easy to be separated from the solutions.

\section{Conclusions}

A novel composite photocatalyst (FaBi) was synthesized, characterized and applied to photocatalytic degradation experiments of $\mathrm{MB}$ in solution. The characterization results of composite catalyst demonstrated that, $\mathrm{BiVO}_{4}$ was successfully loaded on the surface of magnetic glass microsphere, and the saturation magnetization was $27.52 \mathrm{emu} / \mathrm{g}$. The photocatalytic experiments suggested that $\mathrm{FaBi}$ exhibited excellent photocatalytic performance under visible light, and it could effectively promote the photocatalytic degradation of $\mathrm{MB}$ in solution. In addition, the photocatalytic activity of composite catalyst was basically stable after several times of repeated uses. The degradation mechanism of photocatalytic reaction could be attributed to two points: the direct redox of free electrons and free holes produced by $\mathrm{BiVO}_{4}$ under visible light, and the indirect free radical reaction related with free electrons and free holes. Moreover, the pseudo-first-order kinetic equation and Langmuir adsorption isotherm could satisfactorily fit the degradation process of system. Furthermore, the photocatalytic properties of $\mathrm{BiVO}_{4}$ (calculated energy band is $2.213 \mathrm{eV}$ ) under visible light was demonstrated by DFT calculation. These findings indicate that magnetic glass microsphere can be used as a favorable magnetic carrier for photocatalysts.

\section{Conflict of Interest}

The authors declare no conflict of interest.

\section{References}

1. ANANDANA S., PONNUSAMYB V.K., ASHOKKUMARC M. A review on hybrid techniques for the degradation of organic pollutants in aqueous environment. Ultrasonics Sonochemistry, 67, 105130, 2020.

2. ZHANG Q., ZHANG P.Y., YE, J.P., TAO X., WANG S.Q., BAO S., WANG X. Optimization of Anaerobic Biological Treatment Process for High Concentration Organic Wastewater Based on Rural Environmental Pollution Control. Acta Microscopica, 28, 1031, 2019.

3. FU L., BAI Y.N., LU Y.Z., DING J., ZHOU D.D., ZENG R.J. Degradation of organic pollutants by anaerobic methane-oxidizing microorganisms using methyl orange as example. Journal of Hazardous Materials, 364, 264, 2019.

4. MOJIRI A., ZHOU J.L., ROBINSON B., OHASHI A., OZAKI N., KINDAICHI T., FARRAJI H., VAKILI M. Pesticides in aquatic environments and their removal by adsorption methods. Chemosphere, 253, 126646, 2020.

5. LEUDJO TAKA A., FOSSOKANKEU E., PILLAY K., YANGKOU MBIANDA X. Metal nanoparticles decorated phosphorylated carbon nanotube/cyclodextrin nanosponge for trichloroethylene and Congo red dye adsorption from wastewater. Journal of Environmental Chemical Engineering, 8 (3), 103602, 2020.

6. SUBRAMANIAN S., KOKULNATHAN T., TAMIZHDURAI P., CHIU T.W. Activated Graphite Supported Tunable Au-Pd Bimetallic Nanoparticle Composite Electrode for Methanol Oxidation. Journal of nanoscience and nanotechnology, 20 (10), 1, 2020.

7. GAO N., ZHOU Y.K., FAN M.J., XU H.T., CHEN Y.W., SHEN S.B. Promoting effect and role of alkaline earth metal added to $\mathrm{ZrO}_{2}-\mathrm{TiO}_{2}$-supported $\mathrm{CeO}_{2}$ for dichloromethane oxidation. Chemical Engineering Journal, 396, 125193, 2020.

8. KONG X.Y., ZHOU Y.H., XU T., HU B.N., YU G. A novel technique of COD removal from electroplating wastewater by Fenton - alternating current electrocoagulation. Environmental Science and Pollution Research, 27 (13), 15198, 2020.

9. KUMARAN V., SUDHAGAR P., KONGA K.A., PONNIAH G. Photocatalytic degradation of synthetic organic reactive dye wastewater using $\mathrm{GO}^{-\mathrm{TiO}_{2}}$ nanocomposite. Polish Journal of Environmental Studies, 29 (2), 1683, 2020.

10. RASTKARI N., ESLAMI A., NASSERI S., PIROTI E., ASADI A. Optimizing Parameters on Nanophotocatalytic Degradation of Ibuprofen Using UVC/ZnO Processes by Response Surface Methodology. Polish Journal of Environmental Studies, 26 (2), 785, 2017.

11. ZHU N.Y., TANG J., TANG C.L., DUAN P. F., YAO L.G., WU Y.H., DIONYSIOU D.D. Combined CdS nanoparticles-assisted photocatalysis and periphytic biological processes for nitrate removal. Chemical Engineering Journal, 353, 237, 2018.

12. REDDY C.V., REDDY I.N., RAVINDRANADH K., REDDY K.R., SHETTI N.P., KIM D., SHIM J., AMINABHAVI T.M. Copper-doped $\mathrm{ZrO}_{2}$ nanoparticles as high-performance catalysts for efficient removal of toxic organic pollutants and stable solar water oxidation. Journal of Environmental Management, 260, 110088, 2020. 
13. LI Y., XING X.Y., PEI J.Z., LI R., WEN Y., CUI S.C., LIU T. Automobile exhaust gas purification material based on physical adsorption of tourmaline powder and visible light catalytic decomposition of $\mathrm{g}_{-} \mathrm{C}_{3} \mathrm{~N}_{4} / \mathrm{BiVO}_{4}$. Ceramics International, 46, 12637, 2020.

14. ZHAO W.L., WANG W.L., SHI H.F. 2D/2D Z-scheme $\mathrm{BiO} 1-\mathrm{XBr} / \mathrm{g}-\mathrm{C} 3 \mathrm{~N} 4$ heterojunction with rich oxygen vacancies as electron mediator for enhanced visiblelight degradation activity. Applied Surface Science, 526, 146925, 2020.

15. TIAN N., HUANG H.W., WANG S.B., ZHANG T.R., ZHANG Y.H. Facet-charge-induced coupling dependent interfacial photocharge separation: A case of $\mathrm{BiOI} / \mathrm{g}-\mathrm{C}_{3} \mathrm{~N}_{4}$ p-n junction. Applied Catalysis B: Environmental, 267, 118697, 2020.

16. ZHU L.W., DEPARTMENT B. The synthesis and characterization of $\mathrm{BiVO}_{4}$ materials under photocatalysis. Journal of Changchun Institute of Technology (Natural ences Edition), 20 (02), 119, 2019.

17. WANG Y., TAN G.Q., REN H.J., XIA A., LIN B., ZHANG D., WANG M., LV. L. Synthesis of $\mathrm{BiVO}_{4}$ with surface heterojunction for enhancing photocatalytic activity by low temperature aqueous method. Materials Letters, 229, 308, 2018.

18. ULLAH H., TAHIR A.A., MALLICK T.K. Structural and electronic properties of oxygen defective and Sedoped p-type $\mathrm{BiVO}_{4}(001)$ thin film for the applications of photocatalysis. Applied Catalysis B: Environmental, 224, 895, 2018.

19. WANG J., GUO J., ZHANG Y.M. Photocatalytic degradation of methylene blue by magnetically separated visible-light photocatalyst $\mathrm{BiVO}_{4} / \mathrm{Fe}_{3} \mathrm{O}_{4}$. Chemical Research and Application, 22 (5), 544, 2010.

20. KE T.L., GUO H.G., ZHANG Y.L., LIU Y. Photoreduction of $\mathrm{Cr}$ (VI) in water using $\mathrm{BiVO}_{4}-\mathrm{Fe}_{3} \mathrm{O}_{4}$ nano-photocatalyst under visible light irradiation. Environmental Science \& Pollution Research, 24 (36), 1, 2017.

21. YAN W., WANG J., ZHU Y., GUO J., ZHANG Y.M. Preparation and Photocatalytic Properties of Magnetically Separable Visible-Light Photocatalyst $\mathrm{BiVO}_{4} / \mathrm{Fe}_{3} \mathrm{O}_{4}$. Chinese Journal of Inorganic Chemistry, 27 (2), 287, 2011.

22. KRESSE G., FURTHMÜLLER J. Efficient iterative schemes for ab initio total-energy calculations using a plane-wave basis set. Physical review. B (Condensed matter), 54 (16), 11169, 1996.

23. KRESSE G., FURTHMÜLLER J. Efficiency of ab-initio total energy calculations for metals and semiconductors using a plane-wave basis set, Computational Materials Science, 6 (1), 15, 1996.

24. KOHN W., SHAM L.J. Self-consistent equations including exchange and correlation effects, Physical Review, 140 (4), 1143, 1965.

25. NITYANANDA R., HOHENBERG P., KOHN W. Inhomogeneous Electron Gas. Resonance. 22 (8), 809, 2017.

26. PERDEW J.P., BURKE K., ERNZERHOF M. Generalized gradient approximation made simple. Physical Review Letters, 78 (7), 1396, 1996.

27. PERDEW J.,P. CHEVARY J.A., VOSKO JACKON S.H., JACKSON K.A., PEDERSON M.R., SINGH D.J. Atoms, molecules, solids, and surfaces: applications of the generalized gradient approximation for exchange and correlation, Physical Review. B, Condensed matter, 46 (11), 6671, 1992
28. CHEN C., CHENG T., SHI Y.S., TIAN Y. Adsorption of $\mathrm{Cu}$ (II) from Aqueous Solution on Fly Ash Based Linde $\mathrm{F}(\mathrm{K})$ Zeolite. Iranian Journal of Chemistry \& Chemical Engineering International English Edition, 33 (3), 29, 2014.

29. CHEN C., CHENG T., WANG Z.L., HAN C.H. Removal of $\mathrm{Zn}^{2+}$ in aqueous solution by Linde $\mathrm{F}(\mathrm{K})$ zeolite prepared from recycled fly ash. Journal of the Indian Chemical Society, 91 (2), 285, 2014.

30. CHENG T., CHEN C., TANG R., HAN C.H., TIAN $\mathrm{Y}$. Competitive adsorption of $\mathrm{Cu}, \mathrm{Ni}, \mathrm{Pb}$, and $\mathrm{Cd}$ from aqueous solution onto fly ash-based linde $\mathrm{F}(\mathrm{K})$ Zeolite. Iranian Journal of Chemistry \& Chemical Engineering International English Edition, 37 (1), 61, 2018.

31. CHEN C., LI Q., SHEN L.F., ZHAI J.P. Feasibility of manufacturing geopolymer bricks using circulating fluidized bed combustion bottom ash. Environmental Technology, 33 (10-12), 1313, 2012.

32. WANG Y.L., DING K., XU R., LIU B.J. Fabrication of $\mathrm{BiVO}_{4} / \mathrm{BiPO}_{4} / \mathrm{GO}$ composite photocatalytic material for the visible light-driven degradation. Journal of Cleaner Production, 247, 119108, 2020.

33. WANG X.T., ZHOU Z.Q., ZHAO S., CHEN X., YU Y. Synergistic effect of adsorption and visible-light photocatalysis for organic pollutant removal over $\mathrm{BiVO}_{4} /$ carbon sphere nanocomposites. Applied Surface Science, 453, 394, 2018.

34. TAO H.Q., YAO J.F., ZHANG L.X., XU N.P. Preparation of magnetic ZSM-5/Ni/fly-ash hollow microspheres using fly-ash cenospheres as the template. Materials Letters, $\mathbf{6 3}$ (2), 203, 2009.

35. PIISPANEN M.H., ARVILOMMI S.A., BROECK, B.V.D., NUUTINEN L.H., TIAINEN M.S., PERAEMAEKI P.J., LAITINEN R.S. A comparative study of fly ash characterization by LA-ICP-MS and SEM-EDS. Energy \& Fuels, 23 (4), 3451, 2009.

36. ANNA B., LAMBRINI P., ELINA A., KONSTANTINOS S., GEORGE V., EAMONN D., YIANNIS S. Enrichment and oral bioaccessibility of selected trace elements in fly ash-derived magnetic components. Environmental Science and Pollution Research, 24, 2337, 2017.

37. DAI S., ZHAO L., HOWER J.C., JOHNSTON M.N., SONG W.J., WANG P., ZHANG S. Petrology, mineralogy, and chemistry of size-fractioned fly ash from the jungar power plant, Inner Mongolia, China, with emphasis on the distribution of rare earth elements. Energy \& Fuels, 28 (2), 1502, 2014.

38. CHEN K., ZHANG T.S., HUANG L.J., SUO Y.S., ZHANG D.H., SUN J., WANG J.L. A facile and green synthesis of $\mathrm{CDs}-\mathrm{MoS}_{2}-\mathrm{Fe}_{3} \mathrm{O}_{4}$ nanohybrid for recyclable and enhanced photocatalysis in dye degradation. Materials Letters, 232, 167, 2018.

39. CHIDAMBARAM S., PARI B., KASI N., MUTHUSAMY S. $\mathrm{ZnO} / \mathrm{Ag}$ heterostructures embedded in $\mathrm{Fe}_{3} \mathrm{O}_{4}$ nanoparticles for magnetically recoverable photocatalysis. Journal of Alloys and Compounds, 665, 404, 2016.

40. YANG J., CHEN H.H., GAO J.H., YAN T.T., ZHOU F.Y., CUI S.H., BI W.T. Synthesis of $\mathrm{Fe}_{3} \mathrm{O}_{4} / \mathrm{g}-\mathrm{C}_{3} \mathrm{~N}_{4}$ nanocomposites and their application in the photodegradation of 2, 4, 6-trichlorophenol under visible light. Materials Letters, 164, 183, 2016.

41. LIU X.,YIN Y.J., BIAN G., ZHAI Y.Q., LI Y.M., WANG J.Y., CONG C. Novel magnetically separable $\mathrm{BiVO}_{4} / \mathrm{Fe}_{3} \mathrm{O}_{4}$ photocatalyst: synthesis and photocatalytic performance under visible-light irradiation. Materials Research Bulletin, 89, 297, 2017. 
42. WANG D.E., LI R.G. Photocatalytic Water Oxidation on $\mathrm{BiVO}_{4}$ with the Electrocatalyst as an Oxidation Cocatalyst: Essential Relations between Electrocatalyst and Photocatalyst. The Journal of Physical Chemistry C, 116 (8), 5082, 2012.

43. LIU L., DING L., LIU Y.G., AN W.J., LIN S.L., LIANG Y.H., CUI W.Q. A stable $\mathrm{Ag}_{3} \mathrm{PO}_{4} @$ PANI core@shell hybrid: Enrichment photocatalytic degradation with $\pi-\pi$ conjugation. Applied Catalysis B: Environmental, 201, 92, 2017.

44. LIU L., QI Y.H., LU J.R., LIN S.L., AN W.J., LIANG Y.H., CUI W.Q. A stable $\mathrm{Ag}_{3} \mathrm{PO}_{4} @ g-\mathrm{C}_{3} \mathrm{~N}_{4}$ hybrid core@ shell composite with enhanced visible light photocatalytic degradation. Applied Catalysis B: Environmental, 183, 133, 2016.

45. LIN Z.Z., YANG H., CHEN H.M., OUYANG X.Y., LIU Z.Q. Comparison of the decontamination performance of three permeable bricks: adsorption and filtration experiments. Polish Journal of Environmental Studies, 29 (5), 3225, 2020.

46. AYUB N., EHSAN A.M., CHAUDHRY M.N. Using acidactivated azad kashmir clays to remove cadmium and lead lons from wastewater. Polish Journal of Environmental Studies, 29 (5), 3041, 2020.

47. NASEER R., AFZAL N., HASSAN Z.U., SAEED S., MUJHAHID H., FARYAL S., ASLAM S., REHMAN H.U. Effect of bronsted base on topological alteration of rice husk as an efficient adsorbent comparative to rice husk ash for azo dyes. Polish Journal of Environmental Studies, 29 (4), 2795, 2020.

48. LU Y.X., CHEN J., ZHAO L., ZHOU Z., QIU C., LI Q. Adsorption of rhodamine $\mathrm{B}$ from aqueous solution by goat Mmanure biochar: kinetics, isotherms, and thermodynamic studies. Ecology, Environment \& Conservation, 29 (4), 2721, 2020.

49. PETHKAR P.A., NALAWADE P.M., PETHKAR A.V. Kinetics Study of Methyl Orange Adsorption from Aqueous Solutions using Fly Ash Granules as Low Cost Adsorbent. Journal of Scientific \& Industrial Research, 79, 661, 2020.

50. SUPELANO G.I., GÓMEZ CUASPUD J.A., MORENO L.C., ORTIZ C. Synthesis of magnetic zeolites from recycled fly ash for adsorption of methylene blue. Fuel, 263, 116800, 2019. 